\title{
UNCOUNTED OR ILLUSORY BLESSINGS? \\ Competing Responses to the Easterlin, Easterbrook and Schwartz Paradoxes of Well-Being
}

\author{
Des Gasper \\ Institute of Social Studies \\ PO Box 29776, 2502 LT The Hague, Netherlands \\ gasper@iss.nl
}

Prefinal version of a paper which appeared in 2007 in J. of International Development, 19(4), pp. 473-492. An earlier version appeared as: Working Paper 430, ISS, The Hague, http://repub.eur.nl/res/pub/19189/

\begin{abstract}
The Easterlin paradox concerns slight or negligible increases in personal satisfaction reported as incomes rise beyond high middle income levels. Sister paradoxes highlighted by Easterbrook and Schwartz concern the frequent low or negligible response of personal satisfaction to improvements in various dimensions of life. The paper identifies a range of responses to the paradoxes, shows how these responses reflect a series of different conceptions of the meaning of well-being, and assesses their cogency. It indicates required areas for follow-on research.
\end{abstract}

Keywords:- well-being; Easterlin paradox 


\section{INTRODUCTION}

What is the meaning of the very marked levelling-off of reported subjective wellbeing (SWB), felt satisfaction, as national per capita incomes grow beyond $\$ 10,000$ p.a.? Above \$13,000 in 1995 purchasing power there is no significant linkage at all (Inglehart \& Klingemann, 2000, p. 171). Is SWB a relevant measure? Do the rich fail to count their blessings, or is whatever it is that income measures a poor indicator for well-being? In some respects increased income translates into improvements in objective well-being (OWB), meaning authoritatively identified priority aspects of life (such as physical and mental health), but in other respects not. Even gains in OWB frequently fail to bring gains in SWB. What should we make of this?

These puzzles have relevance for lower-income countries whose upper income groups are longstanding denizens of this income space, from where they radiate messages around their society. The notion of ever more fulfilment from ever more income determines much of these countries' current societal design and struggles.

To discuss 'well-being' and its paradoxes we must give attention, first, to what are key aspects of 'being', the ontology of human living; and second, to the variety of relevant normative criteria, the determinants of the 'well' in 'well-being'. This leads us to an overview of conceptions of well-being. With that grounding, we can look at the often markedly divergent findings on income, subjective and objective well-being, and address the explanatory and policy conundrums that arise. We will successively examine: first, stances that simply prioritise other types of data than SWB, holding that we should refer to actions or stated preferences or the conventional measures of OWB; second, direct attacks on SWB data as having little or no normative weight; third, replies which propose that SWB is a good proxy for a more adequate formulation of OWB. The paper concludes with two suggestions: that the specifics of the paradoxes of well-being require that we connect to substantive theories of need; and that while policy in poor countries should give priority to OWB for reasons explored by Sen (1985) and others, in rich countries the priority arguably lies with raising SWB, not with endlessly augmenting OWB construed in terms of criteria of a past era if those are now adequately fulfilled. Otherwise stated, we must update our picture of OWB to learn from the experience of the levelled-off SWB of the rich. 


\section{A GRAMMAR OF WELL-BEING}

\subsection{Aspects of be-ing}

The concept of well-being (WB) is used to refer to any and all of many well-evaluated aspects of life (Gasper, 2007a). We should distinguish at least three levels: first, having, the holding of resources and things; second, living as being and doing, as activity (and the potentials for activities); and third, mental states, feelings, satisfactions. For each level we may distinguish categories of well- and ill-being.

In this paper we concentrate on the discrepancies found between changes in resources and changes in favoured doings and good feelings. It is true that for each level, issues of multi-dimensionality arise strongly. There are numerous diverse significant aspects of how people live, in terms of what they do or can do, as seen in every study of quality of life: how healthy they are, how secure, how free, how able they are to decide or share in decisions. Resources too are not fully commensurable: for example, rights and entitlements versus income and wealth. For the third level too, feeling, people have more complex appreciative systems than a single happinessgauge. Even the simpler, hedonic stream of Subjective Well-Being research in psychology distinguishes three major aspects of well-being which vary partly independently of each other: experiences of happiness, experiences of unhappiness, and experiences of contentment. People hold diverse values that are not simply and fully commensurable, and have diverse and distinct types of well-feeling and illfeeling. Nevertheless, we can and should still compare the directions of change of important overall indicators of opulence, well-living, and satisfaction.

Mainstream economics has in practice treated each person's 'utility' as a supposed unitary well-feeling (which Pareto had called 'ophelimity', as distinct from 'utility' in the sense of usefulness) or subsequently as preference-fulfilment. It is measured ordinally and held to rise with real income. The focus has been on having, having much (cf. Fromm, 1978), although some forms of consumption, like heavy alcohol intake, damage the consumers and those close to them. The Aristotelian tradition takes well-being instead as well-living, the fulfilment of a deep and various human nature, not just one particular type of sensation (Segal, 1991). Ryan \& Deci (2001) call the conception of well-being as happiness or pleasure the hedonic conception, versus the eudaimonic conception of well-being as well-considered fulfilment. 
On this basis, a conceptualisation of well- (and ill-) being should reflect at least the following elementary aspects of human living, which are undervalued or ignored in measures of income and consumption (Gasper 2007a):

- $\quad$ Quantity as well as quality of life

- $\quad$ Time-use patterns; for example, time spent caring for others or commuting.

- Well-becoming (personal growth) and well-dying; we must look at quality of death as part of the Quality of Life.

- Multiple important spheres in a life. Ordinary people's lists of priorities include both 'material' and 'non-material' aspects (Narayan et al. 2000). As remarked by the Chilean economist Manfred Max-Neef (1992), we must speak then of poverties not poverty, for different important things can be lacking: the requisites for survival, health, dignity or flourishing, or survival, health, etcetera themselves.

- Multiple dimensions of living. Max-Neef specifies dimensions of Having, Doing, and Interacting, as well as Being, in each of a series of life spheres. Ekins and Max-Neef (1992) link this perspective to well-being measurement.

- Many aspects of well-being pass outside markets and can be competitive with the market-mediated aspects. Non-market sources - family, friends, health, recreation - appear more important in general for happiness than are market sources, and amongst the market sources, experiences during work hours or unemployment can be more determinant of personal satisfaction than is the level of income or consumption (Clark and Oswald, 1994; Oswald, 1997; Lane, 1998a, 1998b).

Given the diverse relevant aspects of well-being, we should see WB as an umbrella term rather than seek for a single core aspect (Gasper, 2007a). Use of the 'utility' concept often ambiguously bridges between many levels, as we see next.

\subsection{Which types of judgement, about which aspects of being?}

Well-being can be conceptualized at different levels. The traditional economics foci and presumptions can be summarized as a chain: (exogenous) Preferences and Resource endowments $\rightarrow$ Income $\rightarrow$ Choice/ Expenditure $\rightarrow$ Preference fulfilment $\rightarrow$ Satisfaction (utility). To this conventional set of levels, Sen (1985) helpfully added two more: capability and functioning. Each of the levels can be the focus for defining 
and/or measuring poverty. Sen's categories and the work of Doyal and Gough underlie the next two tables.

Table 1

Alternative levels/types of focus in studies of well-being

\begin{tabular}{ll}
\hline $\begin{array}{l}\text { ASPECTS OF LIFE } \\
\text { (Narrative sequence from bottom to top) }\end{array}$ & JUDGEMENTS ABOUT A LIFE / LIVES \\
\hline III. FULFILMENT / SATISFACTION & $\begin{array}{l}\text { III*. PERSONAL JUDGEMENT OF ONE'S LIFE } \\
\text { ('Subjective well-being') }\end{array}$ \\
HUMAN FULFILMENT & $\begin{array}{l}\text { - typically these self-judgements of the quality of } \\
\text { as value fulfilment; more reflective personal } \\
\text { judgements of one's life (e.g. in response to 'Do } \\
\text { you have a good life?') }\end{array}$ \\
$\begin{array}{l}\text { how one lives (see II below) are in the form of } \\
\text { aggregated, synthetic judgements about overall } \\
\text { happiness, satisfaction or fulfilment (= III) }\end{array}$ \\
$\begin{array}{l}\text { 'Are you happy / satisfied?') } \\
\text { (Satisfaction is in fact not a unitary category; } \\
\text { different aspects can be distinguished) }\end{array}$ & $\begin{array}{l}\text { - the judgements are highly variable, in several } \\
\text { ways, as seen in material on SWB ranking of } \\
\text { different countries (e.g. World Values Surveys) }\end{array}$
\end{tabular}

'Utility' - as DESIRE FULFILMENT

\section{HOW PEOPLE LIVE}

FUNCTIONINGS

- e.g. longevity, morbidity [physical and mental], mobility

\section{O-CAPABILITY}

(O for options; the range of lives which people could attain.) Hard to measure; often functionings are taken as the proxy. But see e.g. medical measures of (dis)ability.

\section{S-CAPABILITIES}

(S for skills; people's skills and capacities); and other characteristics of people CHARACTERISTICS OF GOODS, which are acquired through consumption.

CONSUMPTION proper

- viz., actual use of purchases / acquisitions.

\section{INPUTS}

PURCHASES and other acquisitions

'Utility' as $\mathrm{CHOICE}$, which is assumed to reflect preference, and (as the base case) is weighted according to purchasing power. These assumptions have been normal in economics; including 'revealed preference' as an axiom.

INCOME AND RESOURCES / POWER TO ACQUIRE GOODS/ COMMODITIES

\section{PUBLIC JUDGEMENTS OF A PERSON'S LIFE OR PERSONS' LIVES \\ ('Objective well-being') \\ - identification by some authoritative agency of some aspects of life (some functionings, some O- $\&$ S-capabilities) that are considered as of (special) importance/priority \\ - can include aspects of physical/non-human environment \\ - these judgements are usually made for purposes of prioritization in allocation of public resources - often these public judgements are disaggregated / non-aggregated \\ - but they can also be aggregated, e.g. the PQLI (Physical Quality of Life Index), which requires public identification of relative weights}

\section{V. (Money-metric) INFORMATION ON INPUTS}

Monetized measurement of inputs, with valuation according to market principles; including principle of consumer sovereignty etc.

Using a wider perspective, inputs include many features of the social and physical environments relevant to the power to acquire many other basic goods: political freedom, dignity, rewarding personal relations, satisfying meanings, ... 
Table 1 presents an elaborated set of levels, grouped into the three ranges: inputs, outcomes, and responses. The three ranges match the contrasts that we saw earlier: having - being/doing - feeling. The table includes rows for each of the interpretations of well-being which are prevalent. Value fulfilment is worth highlighting separately, outside the rows for desire fulfilment or functionings.

Many of the main determinants of well-being, such as family life and friendship, personality, belief systems, meaning-making and role designations, are not highlighted in this economics-derived perspective. It still helps us to see how different conceptions of the content of well-being typically focus on different levels in the narrative sequence. Table 1's second column shows three main types of conception: personal judgements of quality of life; public judgements of the content and conditions of a life; and (often monetized) measures of the resource inputs to living, including income. Within these broad swathes we need to distinguish further.

\subsection{Seven families of concepts of well-being}

Seven well-being concepts are presented in the first column of Table 2 below, and are matched to, in the second column, the levels of focus in studies of well-being which we saw in Table 1. The set elaborates Parfit (1984)'s well-known list (happiness; preference fulfilment; 'objective list'), in light of Sen's categories. 
1 To judge well-being in practice, the routine operationalization of well-being in much applied economics has traditionally focused on level 1A: control over or power to acquire commodities, as indicated by real income and wealth; and level 1B, expenditure, the acquisition of commodities (as observed by, for example: Kanbur, 2003; Layard, 2005). '...it is fairly standard to equate wellbeing or utility with income' (Graham, 2004, p. 156) ${ }^{1}$; and this is even more so in presentations by political and business leaders. In Sen's terms this focus on control over things is a focus on opulence.

Table 2

Relating concepts of well-being to the stages in Sen's enriched narrative of consumer choice, consumption and functioning

CONCEPT OF WELL-BEING
(based on Gasper 2005, 2007b;
read from bottom to top)
4D: Objective list IV
7: Pleasure/satisfaction
= SWB (if we presume a crude mental model)
6B. Preference fulfilment II
4C. Objective list III
(the central OWB focus)
5. Capability / positive freedom

4B. Objective list II

4A. Objective list I

3. Activity

1B. Opulence II

2. Choice

(6A. Preference fulfilment I)

1A. Opulence I
ALTERNATIVE LEVELS OF FOCUS IN STUDIES OF WELL-BEING

(putative narrative sequence from bottom to top; see Table 1)

HUMAN FULFILMENT

as value fulfilment

'Utility' - as HAPPINESS \&/OR SATISFACTION (not a unitary category; different aspects can be distinguished)

'Utility' - as DESIRE FULFILMENT

FUNCTIONINGS

(other than satisfaction)

\section{CAPABILITY}

(the range of lives which a person could attain)

CAPABILITIES (people's skill and capacities); and other characteristics of people

CHARACTERISTICS OF GOODS, which are acquired through consumption.

CONSUMPTION proper

- viz., actual use of purchases / acquisitions.

PURCHASES and acquisitions

'Utility' as CHOICE, which is typically assumed to reflect preference and weighted according to purchasing power.

INCOME AND RESOURCES / POWER TO ACQUIRE GOODS/ COMMODITIES

1 'the standard way of operationalizing well-being in empirical work [in economics remains as] a simple sum of expenditures on consumption goods' or in terms of income (Kanbur, 2003, p. 3). 
2 Economists also used the concept of revealed preference, the presumption that choices fully reflect preferences. There are two associated conceptions of wellbeing that focus neither on things nor on further outcomes. First, since the presumption that choices fully reflect preferences is incorrect, the associated stance may rather be that well-being lies in making choices, whether or not these prove to fulfil ex ante preferences or promote other approved results. Second is the stance that well-being consists in the fulfilment of (ex ante) preferences, regardless of the real outcomes they bring. Since preferences can be formulated for and focused upon outcomes at various levels - commodities, characteristics, functionings, and so on - the conception of WB as preference fulfilment itself emerges at several levels. Two are indicated in the table: 6A fulfilment of preferences for obtaining certain goods, and $6 \mathrm{~B}$ - fulfilment of preferences for attaining certain functionings.

3 A third broad conception of well-being is as activity per se. It spans aspects of choice, purchase and consumption, but also includes the busy-ness element in other functionings, and the stages of activity that precede and lead up to income and resources. In face of the accumulated evidence of a hedonic treadmill, where after some point ever more business activity leads to no or few hedonic gains (and probably smaller gains than if they were not pursued via the path of commodity production, acquisition, bonding and discarding), this activist conception of well-being may adopt a Promethean defiance (cf. Henry Bruton's The Search for Well-Being (1997)).

4 A series of stages in the narrative correspond to different 'objective-list' conceptions of well-being, or different sorts of component in 'objective lists':certain authoritatively approved characteristics acquired through consumption; authoritatively approved capabilities, in the sense of skills and abilities; authoritatively approved functionings (such as long and healthy life); and value fulfilment or eudaimonia. I group them here as variant conceptions of objective well-being (OWB).

5 Treated separately in the classification is Sen's category of capability. It too might be treated as an objective-list conception (Gasper, 2006), but has achieved independent prominence and has a special character since it concerns potential rather than actual outcomes. 
6 Preference fulfilment has been purportedly central in economists' treatment of well-being. Having retreated from direct attention to utility as felt well-being (ophelimity), unlike psychologists, and often even from attention to utility as the possession of useful characteristics or the performance of useful functionings, as studied by many sociologists, psychologists, designers, engineers and planners, economists came to focus in theory on preference fulfilment. In practice however this reduced, as mentioned above, to conceptions 2 and 3, well-being as choice or as sheer activity.

7 Lastly, well-being as pleasure or happiness - SWB, or at least one version of it. This was rarely studied in practice by economists but was left to other disciplines, whose findings most of economics then ignored, until recently the 'economics of happiness' emerged as an active field (e.g. Layard, 2005).

Equipped now with tools for discussing well-being, we can consider its paradoxes.

\section{THE PROBLEMATIC RELATIONSHIPS BETWEEN SUBJECTIVE AND OBJECTIVE WELL-BEING AND ECONOMIC INPUTS}

\subsection{Relationships}

Frequent major discrepancies exist between the movements of (1) income per capita (or other indicators of economic inputs to being, such as economic resource endowments or expenditures), (2) measures of OWB, and (3) measures of SWB. The accumulated evidence looks as follows.

1 Income-SWB. SWB is not well understood on the basis of income per capita. The scenario that best fits the evidence is the Easterlin paradox: SWB increases with income up to middle-income levels (in World Bank terms), and then relatively rapidly levels off. Not only does the slope coefficient become very low or zero beyond high-middle income levels, there is also very significant (socioeconomically significant) dispersion around this central tendency.

To be more precise: first, cross-sectionally within countries, the rich in all countries studied have higher SWB, but not as much more as many people expected, including many of the rich. Income differences explain no more than 4 per cent of SWB variation between people, according to Inglehart and Klingemann (2000). Second, cross-sectionally across countries, surprisingly little 
difference is found between the average SWB ratings in high middle-income, rich and very rich countries. Third, over time within those rich countries studied, almost no relation is found between increasing income and happiness. Notably many studies have reported on these lines for the USA (for surveys see: Easterlin, 2001; Easterbrook, 2004). These phenomena have become known as 'the Easterlin paradox', after Richard Easterlin who has highlighted such data since the early 1970s. It is treated as a 'paradox' notwithstanding the principle of diminishing marginal utility of income, perhaps because the flattening off is so marked and relatively rapid. ${ }^{2}$

2 Income-OWB. While the (lack of) relationship between income and SWB is important, arguably more important is the relationship between economic growth and objective well-being, the reasoned authoritatively publicly endorsed assessment of life quality. Sen's and UNDP's work on human development indicates that OWB is far from invariably strongly positively correlated with access to commodities via income. One darker paradox might be dubbed 'the California curse': the major, steady rise of reported clinical depression as partner to increasing affluence (Easterbrook, 2004; Schwartz, 2005). In some cases economic growth contributes to OWB, in some cases it does not, and in some cases it damages. In addition, assessments of OWB should not be isolated from sustained experiences of SWB, which contain pointers concerning what are real 'blessings'. OWB criteria can be redefined in light of experience, for example experiences of the emptiness or excess of 'choice', as too much of a good thing.

$3 \quad O W B-S W B$. Easterbrook's The Progress Paradox highlights a puzzle deeper than Easterlin's: large increases in OWB which bring no increase in SWB. Let us for clarity retitle this 'the Easterbrook paradox'. Schwartz's The Paradox of Choice: Why Less Is More concerns one plausible family of explanatory factors behind the Easterlin and Easterbrook paradoxes: how too much choice is a bane, a possibility that is recognised in Sen's capability approach but not highlighted.

4 Overview. Given its unreliable and weak connections with both OWB and SWB, income cannot act as proxy for them. Both, and their various aspects, can sometimes be negatively correlated with income and each other, so that to use

\footnotetext{
${ }^{2}$ While many issues arise in deriving national average SWB ratings from individuals' responses, the Easterlin paradox finding appears solidly established (Easterlin ed., 2002; Frey and Stutzer, 2002).
} 
income or any other variable as proxy for all the others can seriously mislead. We need to look separately at each of: economic inputs; OWB; SWB; the other possible determinants of well-being; and the interrelationships with and causes of those determinants.

5 Other inputs - I. One possible explanation for the Easterlin paradox is that even if higher income would, other things being equal, raise SWB, the generation of the income might have substantial negative side effects on major determinants of SWB like family life. We thus need disaggregated pictures which highlight diverse aspects of life. There are many major aspects of 'objective' well-being, as we saw, such as health, family life, employment, recreation, and quality of death. These are major determinants too of subjective well-being. In contrast to Easterlin and others' findings of often little or no impact of income rises on happiness, some other factors show a stronger correlation with happiness: notably 1. marital satisfaction and other good personal relations, 2. self-esteem and other psychological traits such as extraversion and optimism, 3. selfmanagement skills and feelings of progress towards goals which one accepts, 4 . financial stability, 5. leisure, and 6. religious belief (see e.g. Lane, 1991, 1998a; Myers \& Diener, 1995). Lane and others argue that a preoccupation with material opulence often competes with these other factors, given the mind-set and time-use that it brings.

6 Other inputs - II. However, as noted already, in many cases we find subjective well-being diverging substantially, even radically, from measures of objective well-being too (Easterbrook, 2004; Gasper, 2005). Other major determinants of SWB exist, including for example concerns with status, recognition, relative position, and perceived fairness. In addition, new aspirations emerge.

7 Implications. Thus for both SWB and OWB the main determinants seem often not to be the monetary ones. The realm of means which economics has focused on is often only weakly connected to the worlds of ends, including both satisfaction (SWB) and valued functioning (OWB). Robert Lane calls the weakness of the economics narrative of welfare 'the economistic fallacy' (Lane, 1991). It implies a need for alternative or additional base-narratives which highlight different variables. It also suggests a move beyond the ladder-structure conception (economic inputs $\rightarrow$ intermediate conditions $\rightarrow$ mental events) 
inherited from utilitarianism, although those three categories remain important. We can place OWB and SWB on an equal basis, neither being presumed to be a step on the road to the other.

\subsection{Responses: uncounted blessings or illusory blessings?}

Let us consider some possible explanations for the Easterlin and Easterbrook paradoxes. In the first five types, the findings on subjective well-being are put aside, as epiphenomenal, myopic and/or of no major significance for judging people's lives.

0. [Statistical illusion] One might argue that the puzzling SWB picture is an artefact of the way that data is categorised. If people rank themselves on a 0-100 scale then after a certain point there is no room for further improvement. This does not explain though why people in some middle income countries are in effect already ranking themselves at 90, why Latin American countries dominate the top of some recent SWB league tables, or why Nigeria reportedly topped another recent study. There is a real puzzle to investigate.

A. [Look at people's other words.] Here one emphasises that people still firmly declare that they want more, not less income and/or other goods.

B. [Look at deeds, not words.] Here one argues that preferences are ambiguous, and preference statements are shifting and unreliable for purposes of assessing wellbeing. According to this view, we need to look at behaviour to see real priorities; and behaviour shows that people prioritise having more income, wealth, possessions, and choices, whatever they may say about their situation ex post.

C. [Look at the content of lives, not at feelings.] Expectations grow when opportunities grow, and new unfulfilled ambitions emerge. So, according to this position, we must simply and unapologetically look at the agreed improvements in people's lives, not at moods.

D. [Nature's way.] If one holds that SWB is merely one evolutionary instrument, and is neither the telos for individuals nor for societies, one may judge that SWB data that confirms the Easterlin paradox reflects nothing more morally weighty than the adaptation of preferences and the jading of the familiar: Nature's way to prevent us becoming complacent and non-adaptive. 
In the other three types of explanation the data on subjective well-being is treated as weighty; and either money can't take us to sustained and widely shared high SWB although other things can, or money even takes us down, or nothing can take us there.

E. [Money can't buy me love.] Here one considers that income above certain levels is simply insignificant for SWB - except as a means to symbolize success and try to express superiority.

F. [Money crowds out other values.] Arguably, acquisition and disposal of incomes above such levels requires so much time, preoccupation and a particular mental orientation, that it tends to 'crowd out' other vital features of life, other major determinants of SWB.

G. [Nothing can breach the ineluctable ceiling on SWB.] Lastly, if positional goods goods that concern our position in relation to other people - are central foci for people wishing to display success and express a self-perceived superiority; and if they are particularly important for felt well-being but inherently scarce (Hirsch, 1977); then so is felt well-being. Positional goods include, for example, having the house on top of the hill, 'occupying a chair', or being the first-listed author. In this view, richer people enjoy their relative superiority rather than their opulence. Whether even possession of these positional goods brings sustained high SWB is questionable, since the novelty value evaporates, attention is taken over by new ambitions and new comparisons, and life inevitably runs out and runs down.

We can summarize the issue as: Are people failing to count their blessings, or are the supposed goods not real blessings?

\section{WHICH WAY IS UP? - I: THE DISREGARDING OF SWB - 'WE HAVE BETTER DATA'}

We look first at the sets of arguments for rejecting any direct implication of the Easterlin and Easterbrook paradoxes, through rejecting SWB data as weighty. The arguments we consider in this section correspond to endorsements of the well-being conceptions $2,3,4$ or 6 that we saw earlier. They largely represent different ways to argue that people fail to count their blessings, but the last takes a species-orientation and says that blessings as counted by individuals do not matter (much). Section 5 will probe the direct attacks on the SWB category and clarify the concept; and Section 6 
considers arguments that accept SWB data as weighty and that seek to explore rather than sideline the paradoxes.

Stance A - Look instead at people's other words: 'Take the money!'

When we look at declared preferences, people in general still want more commodities, and do not want to accept less, in all countries. Prioritising this evidence represents adopting well-being theory 6 (preference fulfilment) as opposed to theory 7 (pleasure or satisfaction).

A possible counter argument is that the stance could be deemed internally contradictory. Having rejected the appreciative content of SWB, people's subjectivity elsewhere is invoked and endorsed, where it does not imply any disturbing (contragrowth) conclusions. But whether the stance is consistent or not, we must indeed look seriously at declared preferences. A second counter argument then is that preferences should be well-informed and well-formed - agents should have the relevant information and the relevant skills to process that information effectively - but often are not.

Further, alternative possible explanations exist for why people don't want to accept 'less', rather than on grounds of robust and mature preferences. One possibility is sheer habituation. A second holds that we become caught in an unending circle of temporary gratification through purchases which do not resolve deeper needs and which therefore soon lead to renewed craving and motivate further purchases. Third, the hunt for status and other positional goods means that while in each society richer people are happier, and so each individual may seek more wealth, to have all people wealthier may not make everyone happier or the average person happier. Negative externalities make this a fallacy of composition. If I stand on tiptoe then I can see better, but if all in the crowd do so then no-one sees better, and in addition we get tired, remarks Segal (1998).

Stance B-Deeds not words: 'When it comes to the crunch, people go for economic growth - and a Green Card'

This stance represents well-being theory 2: look at choices, as opposed to what people say about either their present satisfactions or preferences for the future. In sum: let us adopt the revealed preference axiom. A currently popular argument in favour of disregarding the Easterlin paradox runs as follows: if residence permits for the USA 
('Green Cards') were distributed free-of-charge on the street in any other country in the world, would there be always plenty of ready takers? From a presumption that the answer is yes, the conclusion is drawn: what people really want is high income plus plenty of choices on how to acquire and dispose of that income.

The counter arguments include these. First, what attracts people to the USA cannot be assumed automatically to be (the chance of) opulence: it may often instead be personal freedom, freedom of expression, family reunion, peace and security.

Second, the revealed preference axiom, that behaviour reveals preferences about outcomes, disregards matters of (a) fallibility in decision making, (b) hope and gambling, and (c) habit, custom, duty and social constraint. In the visas case the type (c) factors could be relevant if there is a 'herd-effect'; fashion is a form of custom and social constraint. The type (b) factors mean that what one observes are in part preferences about risk and about the possibility of a change, not solely a preference for an expected outcome. The axiom assumes too that people are fully realistically informed about life in the USA, and about the chances and significance of opulence. In the related case of human trafficking, where a different sort of entry permit is sometimes offered free-of-immediate-charge (you pay later), we know that many of those who take the offer are far from realistically informed about what awaits them, and that they fail to remedy that lack and instead take a chance. Ex ante preference is thus a relevant but far from sufficient criterion. We need to see how people feel later and how they behave later. Historically, many migrants want to return home, and a substantial portion do so, despite the costs and difficulties. Those who readily could have returned (which is perhaps not a high proportion of immigrants, for example once their children are Americanized) but do not, form parts of the huge repeated samples that corroborate the Easterlin paradox.

Lastly, we should remember that the Easterlin paradox does not begin to appear before about $\$ 10,000$ per capita income. Evidence from strewing around residence permits in countries less affluent than that is irrelevant here, except insofar as many people from groups already above that level use the permits.

\section{Stance C - Look at the content of lives, not at feelings}

We should look at how long and healthily and actively people live, and at the freedoms they enjoy. This stance represents well-being theory 4: an objective-list conception, involving one or other articulation of the content of OWB. 
Easterbrook examines the evolution of OWB in the USA in detail, and finds now infinitely less drudgery, for doubled life-spans through to active old age. The question remains how far are OWB increases due to and not merely correlated with income increases? Long, healthy and active lives are attainable without Californian income levels. Life expectancy in Costa Rica exceeds that in the USA.

A focus on OWB is well-justified. However the question whether people in fact (subjectively) enjoy 'the freedoms they enjoy' cannot be ignored. As Table 1 highlighted, OWB assessment involves public judgements about what are priority dimensions in person's lives, to guide public decisions. These judgements will also look at declared feelings. We may come to take for granted and downgrade some things that we still, on reflection, conclude are very valuable. But reflective consideration - one of the things that a money-driven life can crowd out - can also lead us to conclude that in some cases the freedoms are in fact worthless, life-eating distractions which render us more dissatisfied. We will see that Barry Schwartz makes this case for the USA, on the basis of the subjective well-being research led by Kahneman, Diener, Seligman and others (Kahneman et al, 1999; Seligman, 2002).

Important aspects of OWB are underlined in Harvard economics professor Benjamin Friedman's defence of economic growth (Friedman, 2005). 'Growing prosperity, history suggests, makes people more tolerant, more willing to settle disputes peacefully, more inclined to favour democracy. Stagnation and economic decline are associated with intolerance, ethnic strife and dictatorship' (The Economist, 2005). Friedman extrapolates an $18^{\text {th }}$ century argument that was surveyed and historically situated by Albert Hirschman (1977). The issue is not whether this argument holds good for $18^{\text {th }}$ century Europe, or contemporary Africa, the former Soviet Union and other lands below the Easterlin deceleration zone around $\$ 10,000$ per capita, but whether it is a universal truth or otherwise justifies the onward march of rich country consumerism. Would the meltdown of the polar ice-caps promote tolerance, democracy, and willingness to settle disputes peacefully?

\section{Stance D - 'The importance of being dissatisfied'}

A final argument for ignoring the Easterlin paradox's apparent implication to turn away from economic growth, or the Easterbrook paradox's possible pointer to rest from further 'improvements', refers to our biological heritage. It holds that insofar as satisfaction induces us to relax it would be of negative selective advantage. Evolution 
has built us for effort and performance, not primarily for satisfaction. We have more powerful internal drivers than SWB. This stance may underlie well-being conception 3: well-being as sheer activity.

The evolutionary advantage of unending effort would not vindicate melting the polar ice-caps. The melting of the ice-caps, and other such scenarios, exemplify how comfort and habit induce us to relax, to our selective disadvantage. Changing the habits of the era of fossil-fuel based economic growth is the path that requires in some ways more effort, not the path of 'keep on trucking'. Secondly, our genes and habits need not dictate to us. Fortunately, our genes sustain the capacity too for intelligent, creative reflection.

\section{WHICH WAY IS UP? - II: THE MEANING AND POSSIBLE REJECTION OF SUBJECTIVE WELL-BEING}

Underlying the stances that downgrade the Easterlin and Easterbrook paradoxes is a downgrading of SWB reports. To assess what is involved here we must be clear about the meaning of 'subjective well-being'. It refers to feelings of (dis)pleasure, (dis)satisfaction or (dis)content, not to methods of measurement. Downgrading of SWB reports cannot be based on inherent unreliability of measurement, but involves instead an assertion of the inherent unreliability or triviality of what is measured, people's feelings.

\subsection{The language of 'subjective versus objective' measures of WB}

A single contrast between 'subjective and objective indicators of welfare' oversimplifies. At least three distinct dimensions are involved: 'Who decides focus?', 'Look at what?' and 'Look how?'. 'Objective' measures of well-being also always reflect a set of values, that determine the answer to 'Look at what?' - we only measure here what is proposed as of value. 'Objective well-being' is inevitably a normative concept. The question is how well-argued and/or widely-accepted those values are. For example, assessing lives in terms of longevity, morbidity, and the requirements for autonomy of agency gives a value-laden but cogent, widely accepted, subject-independent conception of well-being (cf. Doyal \& Gough, 1991). Further, criteria of subjective satisfaction and mental state can certainly be major elements within a well-argued and widely-accepted set of values behind an OWB 
concept. Some of the other 'authoritatively identified' components of well-being may well vary between cases.

The three dimensions are too easily conflated, to produce a single contrast between (1) externally made estimates, expert assessments, of aspects of people's lives and circumstances that are selected by authoritative public values/processes/ representatives and (2) personally provided reports of a subject's own feelings about his/her life. Yet several other cases are relevant. Feelings can still be 'objectively' studied by externals (e.g., monitoring of types of brain function and physiological indicator that express SWB); and self-reports on feelings can be sometimes valid and reliable measures - precisely of what they aim to measure, people's feelings. Since some cases are less common though, the classification often gets concertinaed. The intuition arises that a private-values perspective equates to use of self-report, and a public-values perspective equates to external measurement. Further, since value questions are embarrassing, even the choice of values-perspective can become hidden, and OWB v. SWB is presented as if it was a matter of measurement method only.

In the Easterlin and Easterbrook paradoxes, the meanings attached to SWB and OWB concern the contrast between feelings and circumstances; not who decides on focus (e.g. decides which circumstances, which feelings), nor methods of measurement. They emphatically concern individual wellbeing, not other foci, even though in practice we often compare nations, localities, etc., but viewed as aggregated individuals not as a different sort of entity.

Measures of SWB can acceptably estimate certain perceptions (Myers \& Diener, 1995; Kahneman et al., 1999). This finding concerns the focus and quality of the measurement, not necessarily the stability, uniqueness or good judgement of the perception that is measured. Kelman casts doubt on 'the whole notion...that there is some objective state of subjective well-being apart from our mental construal of it, apart from the stories we tell ourselves about how happy we are' (2005, p. 402), stories which, while told at a particular moment, can be and perhaps soon are told in various different ways. Let us look further at the contingency of subjective wellbeing. 


\subsection{How we don't reliably count our blessings -- and in this case undercount them}

First, SWB current reporting is comparative. Psychology research shows that SWB is highly conditional on 'framing effects'; for example, conditional on with whom/when/ where one compares one's present situation. Frank (1997) notes how strongly in the USA the satisfaction from consumption depends on how the consumer's consumption level relates to his/her previous consumption level and to the consumption level of his/her reference group. I compare, therefore I am. We compare, remarks Easterbrook (2004), firstly with the past - notably with the Golden Age of our childhoods, which typically nothing can surpass; secondly with our expectations - and expectations characteristically rise, for various reasons, including through comparisons; and thirdly against others, partly due to increasing dissemination of fantastical images of ideal people as performance norms. Experimental evidence indicates that most people prefer a better relative resource position even when it is a worse absolute position (Schwartz, 2005, p. 190) - an embarrassment for Rawls's difference principle which posited the opposite.

Second, current SWB is adaptive. Adaptive preferences (sometimes called 'response shift') are widespread. Commonly one's preferences and perceptions adjust to one's situation, however good or bad, to reinterpret it as normal and tolerable. We quickly get used to things and typically come to like what we have ('the endowment effect'). Cummins and others hold that such adjustments are not merely widespread but normal. Such shifts strengthen the case for subject-independent measures, as Sen, Nussbaum, Sunstein and others have argued.

Schwartz (2005) presents the processes of 'hedonic adaptation' in more detail, as having four aspects. 1. We get used to something: an experience stops feeling so good or bad; 2. we re-frame, change our reference points (e.g. develop new or drop old aspirations), so that the same level of feeling stops feeling good enough (Kahneman, 1999); 3. we find silver linings (and leaden downsides?); and 4. we develop coping skills in face of adversity (and lose them in face of good fortune?).

Thirdly, more generally, we can often simply mis-assess our situation (Kagan, 1994). SWB recall is distorted: it appears to be largely determined by peak- and endlevels (Schwartz, 2005, p. 49). And SWB prediction is fallible: expected utility diverges from subsequently experienced utility, for many reasons (Schwartz, 2005). We: mis-predict our preferences; face information overload, including much mis- 
information; overweight unrepresentative vivid bits of evidence (e.g. the experience of a friend); and are misled by (often deliberately) misleading frames of reference (e.g., an advertiser claims that 'the regular price is X'). So measures of SWB cannot be identical to those for quality of life. This is quite apart from the possibility, recognised in literary tragedy and also by Sen, that one may be committed to goals which do not give one SWB.

Fourthly, there may be a series of negative biases built into subjective perception (though authors like Hirschman identify some rosy biases too; Gasper, 1986). Easterbrook (2004) puts forward the following:-

- Attention is purposive not comprehensive, and is therefore negatively biased. We focus on the current problems, not the healthy big picture; and on threats, partly thanks to our evolutionary inheritance but also because we learn to worry about threats, conceivable problems that might require action. We are prone to 'anticipation-induced anxiety' (Easterbrook, 2004, p. 175).

- $\quad$ SWB is culturally moulded and we have inherited a presumption that life is tough.

- $S W B$ is currently influenced by opinion-formers with negative bias: gloomgenerators. Fund-raisers and power-seekers claim, and stress, crises, especially in a system of competitive party politics; news media attract audiences by crisis claims; the ever greater global media coverage supplies ever more tales of woe, 24/7; apocalyptic religion grows; intellectuals seek attention. Crisis claims win attention because attention is purposive and problem-oriented.

- People (often) have negative bias, because of egoism ('I deserve everything I've got, and more; so I should be resentful not thankful'), resentment (having a grudge, an excuse, exempts me from obligations), and natural selection, which favoured discontent and striving.

We cannot, however, ignore the information in measures of SWB. They tell us about something(s) different and important, people's feelings. If people did not feel, then we would be less likely to feel for and with them and to be motivated to help the disadvantaged. The messages which the measures bring concerning such important variables remain massively significant. For even if preferences are often adaptive and distorted, the gap that SWB data shows between the weak or negligible impact of increases in measured real income and the substantial impacts of other promotor factors on SWB in richer countries is one of the major findings of modern social 
science (Easterlin ed., 2002). While such impact findings are less common (although so is the research) they occur sometimes in poorer countries. They should lead us to review not only how we measure but also how we live.

\section{WHICH WAY IS UP? - III: THE PARTIAL DEFENCE OF SUBJECTIVE WELL-BEING}

\subsection{The 'blessings' are not real?}

We have seen a series of positions that indirectly sideline SWB information or headon query its usefulness. The counterarguments in this section present the private discontents of the well-off as normatively weighty information that reflects how major aspects of affluence are not real blessings and should not be included in the public prioritizations that generate our OWB measures.

Easterbrook and especially Schwartz present a wide menu of possible explanations of how affluence can take away with one hand what it gives with the other. In some cases the same factors are mentioned here as for discounting SWB, but they are seen now in another perspective, for example in the view that evolution did not prepare us for handling more than a few options comfortably.

- Abundance creates ever more things that we don't have: more to crave.

- Abundance creates more knowledge of the things that one does not have and that others $d o$, thanks to marketing and wall-to-wall global media; and this knowledge makes one unhappy (Schwartz, 2005, pp. 191-5).

- Abundance increases expectations. It makes us ever more prone to imagine attractive notional scenarios, including retrospectively.

- Ever more types of product, more updates ('new and improved'), built-in obsolescence, and more-complex products with ever more variants lead to: 1 . More time and effort is required in order to choose; 2. Ever more uncertainty that one made the best choice; ever more certainty that one didn't; 3 . Ever more awareness of the imperfection of whatever one chooses, leading in turn to ever more felt losses and regret. Much evidence indicates that when we value something in the context of a wide set of perceived options we value it less (for example, the last essay marked versus the first). The larger the set of options, the stronger this effect, because we become aware of ever more qualities lacking in the thing that is being valued. In addition: 4 . the more options that one has, the 
more of a statement that the choice becomes, the more we feel that others will judge us accordingly, and the more embarrassed we can feel.

- The more the effort in choosing, the more the required pay-off, and the more the frustration later when hedonic adaptation inevitably recurs (Schwartz, 2005, p.179).

- Ever more choice does not lead to ever more felt control, thanks to escalation of expectations and information overload; yet a feeling of control over one's life is central to well-being, concludes Seligman and his school in psychology. Easterbrook, Schwartz and Seligman relate the sustained and rapid growth of depression in the USA to rising expectations for outcomes and rising expectations about individual control and responsibility.

- Constantly thinking in terms of opportunity costs has enormous direct costs and opportunity costs - including the costs of unceasing cogitation and continuing preoccupation with the benefits foregone. Always thinking about options frustrates us, through failure to commit to the course taken, both mentally and in activity. Writing off 'sunk costs' (old possessions, old commitments, old relationships) frustrates us too, despite being part of the logic of 'keep on calculating and choosing in light of all your present options', for it can undermine our sense of self-esteem and meaning. We face ever more such choices as life-options increase.

- Ever more choice induces ever more comparisons with others, which frustrate.

- The spread of maximizing attitudes frustrates (and conduces to depression), for they mean even more time spent choosing and even more regret at the imperfection of choice. Their spread is a result of, first, the growth of options and the wish to avoid the thereby increased danger of regret (but, ironically, trying to maximize typically increases regret because it raises awareness of opportunity costs); and second, the increase of comparisons, as information spreads. (Schwartz, 2005, chapters 4 \& 9)

- Ever more options means ever more value-trade-offs, which we hate to make (Schwartz, 2005, chapter 6).

- Stress follows from getting into debt, and may lead us to spend yet more; a workspend-borrow treadmill. 


\subsection{The real blessings are scarce and under threat?}

Counterpart to this analysis of the possible hollowness of superabundance, Easterbrook and Schwarz draw from the literature a set of generalizations about what factors bring sustained satisfaction and do not frustrate. The 'real blessings' include: loving and feeling loved; fellowship; rewarding activity; sources of meaning and foci for commitment; sources of assurance in our finite lives; and so on. These basics are jeopardised, they report, at least for the USA, by increasing loneliness, overwork, under-sleeping, overweight and highfat diets (Easterbrook, 2004, chapter 6). Depression increases, from loneliness, pressure and expectations. Fixation on purchasable goods both fails to deliver sustained satisfaction directly - many of the blessings are not real - and indirectly undermines the achievement of other goods.

People are misled by 'hedonistic disconnect', the idea that they can get sustained happiness directly from things, with affluence not understood as an opportunity-giving platform for experiences beyond it, but instead presumed to be the end itself. Taking the opportunity requires engagement in significant activities and relationships, and also requires skills such as the skills of gratitude, including to our forerunners, and of forgiveness of others, including our parents (Easterbrook, 2004, chapter 8). Such engagement requires time, which is at risk of instead being consumed by consumption and work. The freedom to choose between very many slightly different goods is not a fundamental freedom. Freedom of choice can easily become tyranny of choice, Schwartz concludes.

\section{CONCLUSIONS: SUSTAINABILITY, NEEDS, AND WELL-BEING}

\subsection{Facing or ignoring the discrepancies}

The discrepancies in the movements of incomes, circumstances and satisfactions are responded to differently by the different theories/conceptualizations of well-being that we have seen. Perhaps the most common response continues to be to ignore the discrepancies and simply presume that inputs are a good proxy for well-being: a definition of well-being as opulence (conception 1 in Table 2's list). This evasion needs socio-psychological and political-cultural diagnosis.

We must investigate the discrepancies by checking the adequacy of our measures and data and the influence of the other variables. We then face four options: 
- To give priority to measures of objective well-being (conception 4 in Table 2); which is often defensible, perhaps especially when we are talking of low-income countries, but those are not the main focus when we consider the Easterlin, Easterbrook and Schwartz paradoxes;

- to give priority to measures of subjective well-being (conception 7);

- to reject both for some other conception of well-being; the leading candidates here adopt a pure-process conception of value, whether as choice (conception 2), preference fulfilment (conception 6), or sheer activity (conception 3); or

- to find a reasoned synthesis of conceptions, such as offered by the capability approach (conception 5) or later in this section.

The capability approach is not directly discussed in this paper (see Gasper, 2002, 2005, 2006 for doubts about its current use). We have looked at each of the other options. I suggested that pure-process conceptions of well-being, as choice or preference fulfilment or activity, are all usually questionable. The remaining three broad options are adopted by, respectively, Easterbrook, Schwartz and the present author.

Firstly, the option of priority to OWB. Easterbrook reviews in depth the SWBOWB discrepancy, an issue which gains its significance if we think SWB has importance. Faced with the difficulty and ambivalence of the issues, he moves back at the end of his book to declare that a future of complaining inhabitants of a dramatically improved world 'is a poignant prospect, but otherwise need not concern us' (2004. p. 317). 'Let them eat cake', even though it does not make them very happy.

Secondly, the option of priority to SWB: 'A bit more of what we like'. Schwartz in contrast argues that in a situation of already high OWB the priority goes to raising SWB not to endlessly augmenting OWB construed in terms of the criteria of a past era which are now amply fulfilled (2005, Annex: 6). So while Sen and others persuasively argued that for low human-development countries (or rather, groups) we should stress OWB more than an SWB that has adapted to help people tolerate or mentally escape hardship and inequity, Schwartz presents for rich countries important reasons for the priority attention to SWB that Layard, Scitovsky and others call for.

Thirdly, a synthetic view: 'A bit more of what we like is what is good for us'. A modified version of Schwartz's position appears plausible: a re-construal of OWB 
to put greater emphasis on mental well-being as well as on the fulfilment of other publicly considered values. This can be expected to converge somewhat with SWB, though the two will not become identical. Already most specifications of quality of life consist of a mixture of 'objective' and 'subjective' indicators (achievements, circumstances and feelings), and the implication is to increase the weight given to criteria of fulfilment, contentment and mental health.

\subsection{Analytical agenda}

A long term growth-OWB link requires environmental sustainability, whereas the preponderance of evidence is that economic growth on current lines seriously endangers sustainability. Part of the attention to the Easterlin and Easterbrook paradoxes - the lack of subjective gain in rich countries from the ocean of consumption in the past fifty years (e.g., the proportion of people in the US who define themselves as very happy has declined since the late 1950s) - arises from hope that sustainability may be best promoted by appeal to people's self-interest: their eudaimonic and even hedonic prudence. The judgement may be that arguments of environmental risk (prudence for the sake of future generations), let alone arguments about the injustices of present economic systems (acknowledgement of the rights and needs and well-being of others who are far less advantaged) will not have as much reform impact as will direct prudence arguments.

If ongoing material accumulation really is relatively dissatisfying and empty, why do we persist? To diagnose paradoxes may have little effect against the systemic factors that promote accumulation and 'hedonistic disconnect'. Any such system of arguments will only have impact under specific conditions. The system must be vivid, cogent (as for example 'the paradox of choice' and 'the California curse' appear to be), based in convincing wider intellectual systems, and connected to a practical alternative that is perceived as feasible, appealing and 'natural': altogether a severe set of requirements.

On the way to an attractive alternative to the conventional inputs-oriented narrative of welfare, our picture of human motivation should adopt the following principles, according to Tim Jackson (2006). First, human beings have a plurality of major motivations, including for meaning and identity. Meanings are part of social living: 'Self is a social construct' (Jackson, ibid, p. 374). The individual is bound into 
a social fabric. Next, 'Material artefacts embody symbolic meanings' (p. 378); they provide semantic and emotional calories. And further, 'Consumer society is a cultural defence against anomie' and the certainty of death (p. 384). A defence is particularly required now that people live long and, in rich countries, face less direct threat. The consumption of the well-off is, he suggests, mainly a pursuit of symbolic meanings and identity through the acquisition and possession of material goods imbued with such meanings. The relative emptiness of consumption allows its endless repetition, wherein the meaning-giving can come more through the process than the product.

Attempts to change consumer behaviour through addressing individuals, via information (for example about paradoxes) and via financial incentives and disincentives, will have little impact warns Jackson, given people's other motivations, social lock-in, and the massive resources of business that pull in the other direction. Instead change must come via peer groups and communities.

Jackson frames his position in terms of 'motivations' and 'functionings' rather than in terms of 'needs', because the language of needs became such a battleground (p. 370); though, as he adds, later needs theorists like Mallmann and Max-Neef refined that language so as to remove much of the cause for battle. A refined needs language allows us to address several central issues clearly (Gasper, 2004, 2007b). Whether we say that something is an overlooked blessing, or that it is not a blessing, we require an argued normative stance on what is a blessing and a sociopsychological theory of well-being (and of looking and overlooking). Progress in face of the Easterlin paradox, the California curse and their siblings calls in other words for a theory of need(s) that contains both explanatory and normative components (see, for example, Doyal \& Gough, 1991; Ryan \& Deci, 2001).

The specificities of the Easterlin paradox underline the importance of this connection to a theory of needs. We observe not a gentle, gradual and modest decline in the gradient of the SWB-income curve, but relatively speaking a rapid and marked flattening. And why doesn't the flattening happen instead in some other income range - around $\$ 3000$ per capita or $\$ 30000$ per capita? The paradox is something quite specific, which underlines its status as a key finding of social science. A substantive needs theory appears essential to explain this particular ensemble: the rising part of the SWB-income curve, the (virtually) flat part, and the location of the transition zone. 
In sum, I have suggested the following. First, understanding the Easterlin and Easterbrook paradoxes requires a conceptualization of human well-being that distinguishes different dimensions and spheres of be-ing (Section 2). Second, understanding the responses to the paradoxes requires distinguishing different normative criteria and concepts of well-being. The major distinct responses reflect seven standard conceptualisations of well-being (Section 3). From application of such an approach (in Sections 4 to 6), I suggested (section 7.1) that, third, a plausible response seems to be to adopt for affluent societies a mixture of OWB and SWB concerns, to conclude that many of the products of contemporary affluence are "not real blessings', and to find OWB specifications that reflect this. Finally (section 7.2), further analytical and policy progress in face of the Easterlin paradox and its siblings calls for increased connection to theories of need, both explanatory and normative.

\section{REFERENCES}

Ackerman F, Kiron D, Goodwin N, Harris J, Gallagher K (eds.). 1997. Human Well-Being and Economic Goals. Washington, DC: Island Press.

Baldwin S, Godfrey C, Propper C (eds.). 1990. Quality of Life - Perspectives and Policies. London: Routledge.

Bruton H. 1997. The Search for Well-Being. Ann Arbor: Univ. of Michigan Press.

Clark A, Oswald A. 1994. Unhappiness and Employment. Economic Journal 104(424), 648659.

Diener E, Biswas-Diener, R. 2000 New Directions in Subjective Well-Being Research. Indian J. of Clinical Psychology 27: 21-33.

Doyal L, Gough I. 1991. A Theory of Human Need. London: Macmillan.

Easterbrook G. 2004. The Progress Paradox. New York: Random House.

Easterlin R. 2001. Income and Happiness: Towards a Unified Theory. Economic Journal 111 (July): 465-84.

Easterlin R. 2002. Introduction. In Easterlin (ed.) 2002; ix-xvi.

Easterlin R (ed.). 2002. Happiness in Economics. Cheltenham: Edward Elgar.

Economist, The. 2005. Review of Friedman B, 2005. 12 November.

Ekins P, Max-Neef M (eds). 1992. Real Life Economics. London: Routledge.

Elster, J. 1983. Sour Grapes. Cambridge: Cambridge Univ. Press.

Frank RH. 1997. The Frame of Reference as a Public Good. Economic Journal 107 (November), 1832-47.

Frey B, Stutzer A, 2002. What Can Economists Learn from Happiness Research? Journal of Economic Literature, XL, 402-435.

Friedman B. 2005. The Moral Consequences of Economic Growth. New York: Knopf.

Fromm E. 1978. To Have Or To Be? London: Jonathan Cape.

Gasper D. 1986 Programme appraisal and evaluation: The Hiding Hand and other stories. Public Administration and Development 6, 467-474.

Gasper D. 2002. Is Sen's Capability Approach an Adequate Basis for Considering Human Development? Review of Political Economy, 14(4), 435-461.

Gasper D. 2004. The Ethics of Development. Edinburgh: Edinburgh University Press.

Gasper D. 2005. Subjective and Objective Well-Being in Relation to Economic Inputs: Puzzles and Responses. Review of Social Economy 63(2), 177-206. 
Gasper D. 2006. What is the Capability Approach? Its Core, Roles, Partners and Pitfalls. Journal of Socio-Economics, 35(6).

Gasper D. 2007a. Human Well-Being: Concepts and Conceptualizations. In Human Well-Being: Concept and Measurement, McGillivray M (ed.). Basingstoke: Palgrave; 23-64.

Gasper D. 2007b. Conceptualizing Human Needs and Well-Being. In Wellbeing in Developing Countries: New Approaches and Research Strategies, Gough I \& MacGregor A (eds.). Cambridge: Cambridge University Press; 47-70

Graham C. 2004. Assessing the Impact of Globalization on Poverty and Inequality. In Brookings Trade Forum 2004. Washington, DC: Brookings Institution; 131-163.

Hirsch F. 1977. Social Limits to Growth. London: Routledge.

Hirschman A. 1977. The Passions and the Interests. Princeton: Princeton Univ. Press.

Inglehart R., Klingemann H-D. 2000. Genes, Culture, Democracy and Happiness. In Culture and Subjective Well-Being, Diener E., Sukh E. (eds.). Cambridge, MA: MIT.

Jackson T, 2006. Consuming Paradise - Towards a social and cultural psychology of sustainable consumption. In The Earthscan Reader in Sustainable Consumption, Jackson T (ed.). London: Earthscan; 367-395.

Kagan, S. 1994. Me and My Life. Summary in: Ackerman et al. (eds), 194-6.

Kahneman D. 1999. Objective Happiness. In Kahneman et al. (eds), 3-25.

Kahneman D, Diener E, Schwartz N (eds.). 1999. Well-Being: The Foundations of Hedonic Psychology. New York: Russell Sage Foundation.

Kanbur R. 2003. Conceptual Challenges in Poverty and Inequality. WIDER Angle, 1/2003.

Kelman, M. 2005. Hedonic Psychology and the Ambiguities of 'Welfare'. Philosophy and Public Affairs 33(4): 391-412.

Lane, R.E. 1991. The Market Experience. New York: Cambridge UP.

Lane, R.E. 1998a. The Joyless Market Economy. In Economics, Values and Organization, Ben-Ner A \& Putterman L (eds.), Cambridge: Cambridge UP; 461-88.

Lane, R.E. 1998b. The Road Not Taken: Friendship, Consumerism and Happiness. In Ethics of Consumption, Crocker D, Linden T (eds.). Lanham, MD: Rowman \& Littlefield; $218-48$

Layard R. 2005. Happiness. London: Penguin.

Max-Neef M. 1992. Development and Human Needs. In: Ekins \& Max-Neef (eds.), 197-214.

Myers D, Diener E. 1995. Who Is Happy?, Summary in: Ackerman et al. (eds), 174-7.

Narayan D, et al. 2000. Voices of the Poor-Can Anyone Hear Us? New York: Oxford UP.

Narayan D, Chambers R, Shah M, Petesch P. 2000 Voices of the Poor - Crying Out for Change. New York: Oxford UP.

Nussbaum, M. 2000. Women and Human Development. Cambridge: Cambridge UP.

Oswald A. 1997. Happiness and Economic Performance. Economic Journal, 107 (November): 1815-31.

Parfit D. 1984. Reasons and Persons. Oxford: Clarendon.

Ryan R.M., Deci E. 2001. On Happiness and Human Potentials: A Review of Research on Hedonic and Eudaimonic Well-Being. Annual Review of. Psychology, 52: 141-66.

Schwartz B. 2005 The Paradox of Choice - Why More is Less. New York: Harper Perennial, expanded edition.

Scitovsky T. 1976. Second edition 1992. The Joyless Economy. New York: Oxford Univ. Press.

Segal, J.M. 1991. Alternative Conceptions of the Economic Realm. Summary in: Ackerman et al. (eds); 15-18.

Segal, J.M. 1998. Living at a High Economic Standard: A Functionings Analysis. In Ethics of Consumption, Crocker D, Linden T (eds.). Lanham, MD: Rowman \& Littlefield; 342365.

Seligman, M. 1991. Learned Optimism. New York: Random House.

Seligman, M. 2002. Authentic Happiness. New York: Free Press.

Sen, A.K. 1985. Commodities and Capabilities. Amsterdam: North Holland.

Sunstein C. 1995. Gender, Caste and Law. In Women, Culture, and Development, Nussbaum M, Glover J (eds.). Oxford: Clarendon; 332-359. 